\title{
FACTORS RELATED TO AMPUTATION LEVEL AND WOUND HEALING IN DIABETIC PATIENTS
}

\section{FATORES RELACIONADOS AO NÍVEL DE AMPUTAÇÃO E À CICATRIZAÇÃO DE FERIDAS EM PACIENTE DIABÉTIICOS}

\author{
Daniel Baumfeld ${ }^{1}$, Tiago Baumfeld ${ }^{1}$, Benjamim Macedo ${ }^{2}$, Roberto Zambelli $1^{3}$, Fernando Lopes $^{3}$, Calo Neri $^{4}$ \\ 1. Hospital das Clínicas, Belo Horizonte, MG, Brazil. \\ 2. Hospital Felício Rocho, Belo Horizonte, MG, Brazil. \\ 3. Hospital Mater Dei, Belo Horizonte, MG, Brazil. \\ 4. Universidade Federal de São Paulo - UNIFESP, São Paulo, SP, Brazil.
}

\section{ABSTRACT}

Objective: There are no specific criteria that define the level of amputation in diabetic patients. The objective of this study was to assess the influence of clinical and laboratory parameters in determining the level of amputation and the wound healing time. Methods: One hundred and thirty-nine diabetic patients were retrospectively assessed. They underwent surgical procedures due to infection and/or ischemic necrosis. Type of surgery, antibiotic use, laboratory parameters and length of hospital stay were evaluated in this study. Results: The most common amputation level was transmetatarsal, occurring in 26 patients (28.9\%). The wound healing time increased with statistical significance in individuals undergoing debridement, who did not receive preoperative antibiotics and did not undergo vascular intervention. Higher levels of amputation were statistically related to limb ischemia, previous amputation and non-use of preoperative antibiotics. Conclusion: Patients with minor amputations undergo stump revision surgery more often, but the act of always targeting the most distal stump possible decreases energy expenditure while walking, allowing patients to achieve better quality of life. Risk factors for major amputations were ischemia and previous amputations. A protective factor was preoperative antibiotic therapy. Level of Evidence III, Retrospective Study.

Keywords: Diabetic foot. Amputation. Antibiotics. Wound healing. Risk factors. Protective factors.

\section{RESUMO}

Objetivos: Não há critérios específicos que definam o nível de amputação em pacientes diabéticos. O objetivo deste estudo foi avaliar a influência de parâmetros clínicos e laboratoriais na determinação do nível de amputação e do tempo de cicatrização da ferida. Métodos: Centro e trinta e nove pacientes diabéticos foram avaliados retrospectivamente. Eles foram submetidos a procedimentos cirúrgicos devido a infecção e/ou necrose isquêmica. Este estudo avaliou tipo de cirurgia, uso de antibióticos, parâmetros laboratoriais e tempo de internação. Resultados: O nível de amputação mais comum foi o transmetatarsal, ocorrendo em 26 pacientes (28,9\%). O tempo de cicatrização das feridas aumentou com significância estatística em indivíduos submetidos a desbridamento que não usaram antibióticos pré-operatórios e que não foram submetidos à intervenção vascular. Os niveis mais altos de amputação foram estatisticamente relacionados a isquemia do membro, amputação prévia e ausência de antibiótico no pré-operatório. Conclusão: Os pacientes com amputações menores são submetidos à revisão do coto com maior frequência, porém, visar sempre o coto mais distal possível diminui o gasto de energia durante a marcha, possibilitando melhor qualidade de vida aos pacientes. Os fatores de risco de amputação maior foram isquemia e amputações prévias. Um fator de proteção foi a antibioticoterapia no pré-operatório. Nível de evidência III, Estudo Retrospectivo.

Descritores: Pé diabético. Amputação. Antibióticos. Cicatrização. Fatores de risco. Fatores de proteção.

Citation: Baumfeld D, Baumfeld T, Macedo B, Zambelli R, Lopes F, Nery C. Factors related to amputation level and wound healing in diabetic patients. Acta Ortop Bras. [online]. 2018;26(5):342-5. Available from URL: http://www.scielo.br/aob.

\section{INTRODUCTION}

Diabetes Mellitus is an extremely debilitating chronic disease that has taken an epidemic pattern in recent decades, becoming a real public health problem. In 2012, the diabetic population in the US was estimated at 29.1 millions of Americans, with 1.4 million diagnosis per year, which generated a 245 billion dollars cost in that same year. ${ }^{1}$ Peripheral neuropathy is a late complication observed especially in the lower limbs and is the main cause of ulcerations on feet. ${ }^{2}$ Secondary infection of neuropathic ulcers is the main cause of hospitalization and amputation of the lower limbs in the diabetic patient. ${ }^{2,3}$ In addition, 2/3 of diabetic patients

All authors declare no potential conflict of interest related to this article.

Work conducted at the Hospital Mater Dei and Hospital Felício Rocho.

Correspondence: Tiago Baumfeld. Rua dos Pampas, 990 - Torre 1/Apto1701, Belo Horizonte, MG, Brazil.30411-030. tiago.baumfeld@gmail.com 
who underwent lower limb amputation died in 5 years due to bed immobilization, inadequate psychologically counseling and uncontrolled food intake. ${ }^{4}$ According to the Brazilian Diabetes Society, every minute in the world, an amputation is performed due to diabetes. In Brazil, the real incidence of diabetes is still unknown. It is estimated that there is something around 8 million diabetics and at least another 3 million that do not have their disease diagnosed. ${ }^{5}$ There is no statistical data that provides any criteria for indicating the correct level of amputation; however, it is known that advanced kidney disease and absence of distal pulse are factors that negatively influence the healing prognosis of diabetic amputated patients. ${ }^{6}$

The objective of this study was to trace the epidemiological profile of persons with diabetes treated at two tertiary orthopedic hospitals and evaluate the influence of clinical and laboratory parameters in the final amputation level of the lower limbs and in the wounds' healing time.

\section{MATERIALS AND METHODS}

Between April 2007 and December 2012, 139 patients were hospitalized due to complications of diabetic foot in two tertiary orthopedic hospitals. All of them were submitted to a debridement or an amputation due to infection and/or ischemic necrosis in that affected limb. Epidemiological data from the 139 patients was retrospectively collected from medical records, consisting in: age, gender, diagnosis, type of surgical procedure, amputation level, wound healing time, culture results, antibiotic usage, need of vascular procedures and hospital length stay. The laboratory tests collected were: White Blood Cell Count (WBC), Erythrocyte Sedimentation Rate (ESR), C-Reactive Protein (CRP), Serum Albumin (SA), Creatinine and Urea. All Patients signed an informed consent. This study was aprooved by our institution ethics committee with the number 078/2015.

Mann-Whitney and Fisher tests were used, according to each analysis, to correlate the studied variables. We adopted the significance level of $5 \%(p<0.05)$ for the application of statistical tests. We used the SPSS software (Statistical Package for Social Science), in its 17.0 version, for analysis of results.

\section{RESULTS}

\section{Descriptive Analysis}

From the 139 patients studied, 106 (76.3\%) were male and 33 (23.7\%) were female. The average age was 64 years, ranging from 23 to 100 years. The average hospital stay was 23 days, with a minimum stay of 1 day and up to 150 days.

The most prevalent diagnoses were: ischemia, occurring in 63 cases (33.3\%); osteomyelitis in 62 patients (32.8\%); and infected ischemia in 34 cases (18\%). We had 187 diagnoses for the 139 patients, with an average of 1.4 diagnoses per patient.

Regarding the surgeries, we had an average of 1.2 surgeries per patient, with 162 procedures. The most prevalent procedure was amputation, performed 90 times (54.9\%), followed by debridement, performed 70 times (42.7\%).

The most frequent amputation level were the transmetatarsal, performed in 28 patients (31.1\%) and the amputation of one toe, performed in 25 patients (27.7\%) (Table 1).

Regardless of the number of surgeries that each patient was submitted, each one of them had the final wound healing time evaluated. The time between the first surgery and the complete closure of the wound had an average of 35 days, with a minimum of 14 days and up to 730 days, in 138 patients that had this information recorded. Twenty-six patients (18.7\%) did not have the final wound closure time recorded and, in three of them, this information was not recorded because the patients died

With respect to the use of antibiotics (ATB), 89 (64.0\%) patients used it before admission, 55 (40.0\%) in the postoperative period and 39 (28.1\%) did not use ATB. In 11 medical records this information was not found. About the ATB used before the admission, most part of the patients used Amoxicillin-Clavulanate (24.7\%), followed by Ampicillin-Sulbactam (23.6\%) and the combination of Ciprofloxacin and Clindamycin (18.0\%). In relation to the ATBs used postoperatively, after adjustment by the culture results, most part of the patients used Amoxicillin-Clavulanate (20.0\%), followed by Ampicillin-Sulbactam (11.3\%) and the combination of Ciprofloxacin and Clindamycin (8.7\%).

Most part of the collected cultures were positive (74.1\%), while $18.0 \%$ had no microorganisms growth. In $7.9 \%$ of the patients this result was not informed. The average number of bacteria found per patient was two. The greater number of bacteria found was three. The most prevalent microorganisms were: Staphylococcus aureus, occurring in 24 cultures (15.6\%), Pseudomonas aeruginosa, occurring in 18 cultures (11.7\%) and Enteroccus faecalis occurring in 15 cultures (9.7\%) (Table 2). The most common association between bacterias was Staphylococcus aureus + Enteroccus faecalis (7 cultures) and Pseudomonas aeruginosa + Enterobacter cloacae (4 cultures). Five cultures were positive for multidrug-resistant Staphylococcus aureus (MRSA). Four of these patients with MRSA had used antibiotics (Amoxicillin-Clavulanate) before admission.

Of the 139 patients evaluated, 49 (35.3\%) underwent some attempt of surgical revascularization of the lower limb. Three patients did not have any records about vascular approach.

\begin{tabular}{c|c|c}
\hline Table 1. Level of Amputation. \\
\hline Level of Amputation & Frequency & $\%$ \\
\hline Chopart joint & 2 & 2.2 \\
\hline Metatarsophalangeal & 4 & 4.5 \\
\hline Ray & 6 & 6.6 \\
\hline Transfemoral & 6 & 6.6 \\
\hline Transtibial & 19 & 21.1 \\
\hline Toe & 25 & 27.7 \\
\hline Transmetatarsal & 28 & 31.1 \\
\hline Total & 90 & 100.0 \\
\hline
\end{tabular}

Table 2. Most common bacterias found in positive culture results.

\begin{tabular}{c|c|c}
\hline Bateria & N & $\%$ \\
\hline Staphylococcus aureus & 24 & 15,6 \\
\hline Pseudomonas aeruginosa & 18 & 11,7 \\
\hline Enterococcus faecalis & 15 & 9,7 \\
\hline Proteus mirabilis & 12 & 7,8 \\
\hline Escherichia coli & 12 & 7,8 \\
\hline Enterobacter cloacae & 10 & 6,5 \\
\hline Klebsiella Pneumoniae & 9 & 5,8 \\
\hline Serratia marcens & 7 & 4,5
\end{tabular}




\section{Comparative Analysis}

The statistical analysis showed that the wound healing time was impacted by several factors (Table 3 ). The wound healing time was longer in those patients in whom preservation of the limb was attempted through serial debridement $(p=0.005)$ or through vascular approach $(p=0.003)$. The wound healing time decreased in those patients in whom the amputation was the first choice of treatment $(p=0.001)$ and in those patients that used ATB before admission $(p=0.000)$

Laboratory parameters were also studied in relation to the wound healing time (Table 4). The only statistically related factor were preoperative WBC ( $p=0.032$ and $r=0.209)$, that were bigger in those patients with longer wound healing time.

Regarding the level of amputation, it was observed that individuals who had higher level of amputation (above the ankle level) were those with associated ischemia diagnosis $(p=0.002)$ and who had already undergone previous amputation $(p=0.010)$. The individuals who had lower levels of amputation (at the foot level) were those who used ATB preoperatively $(p=0.004)$. Patients who underwent minor amputations had more surgical procedures than those who underwent major amputation ( $p=0.002$ ), an expected relationship, as a distal limb preservation require more wound care. There was no significant correlation between the length of hospital stay and the results of cultures $(p=0.311)$. In addition, there was no statistical relationship between length of hospital stay and wound healing time $(p=0.621)$.

Table 3. Evaluated factors Vs. Time between the first surgery and the final wound closure time.

\begin{tabular}{|c|c|c|c|c|}
\hline $\begin{array}{l}\text { Factors influencing in the } \\
\text { wound closure time }\end{array}$ & Category & $\mathrm{N}$ & Average time (days) & $p$ value \\
\hline \multirow[t]{2}{*}{ Amputation } & Yes & 76 & 47.1 & \multirow{2}{*}{$0.001^{*}$} \\
\hline & No & 30 & 69.8 & \\
\hline \multirow[t]{2}{*}{ Debridment } & Yes & 53 & 62.4 & \multirow{2}{*}{$0.005^{*}$} \\
\hline & No & 54 & 45.8 & \\
\hline \multirow[t]{2}{*}{ Antibiotic (before adimission) } & Yes & 69 & 42.7 & \multirow{2}{*}{$0.000^{*}$} \\
\hline & No & 29 & 65.8 & \\
\hline \multirow[t]{2}{*}{ Vascular approach } & Yes & 30 & 67.7 & \multirow{2}{*}{$0.003^{*}$} \\
\hline & No & 76 & 47.9 & \\
\hline \multirow[t]{2}{*}{ Saved limb } & Yes & 83 & 49.9 & \multirow{2}{*}{$0.038^{*}$} \\
\hline & No & 22 & 64.9 & \\
\hline
\end{tabular}

${ }^{*} \mathrm{P}<0,05$

Table 4. Laboratory parameters correlation with wound healing time.

\begin{tabular}{c|c|c|c}
\hline $\begin{array}{c}\text { Pre operative } \\
\text { exam }\end{array}$ & Average & $\begin{array}{c}\text { Correlation } \\
\text { coefficient }\end{array}$ & p value \\
\hline WBC $(/ \mathrm{ml})$ & 5932 & 0.209 & $0.032^{*}$ \\
\hline $\mathrm{SA}(\mathrm{g} / \mathrm{dL})$ & 2.82 & -0.077 & 0.456 \\
\hline Creatinine $(\mathrm{mg} / \mathrm{dL})$ & 1,85 & -0.017 & 0.862 \\
\hline Urea $(\mathrm{mg} / \mathrm{dL})$ & 56 & -0.056 & 0.576 \\
\hline CRP $(\mathrm{mg} / \mathrm{dL})$ & 122 & -0.043 & 0.665 \\
\hline $\mathrm{ESR}(\mathrm{mm} / \mathrm{h})$ & 47 & -0.214 & 0.073 \\
\hline${ }^{*} \mathrm{p}<0.05$ & & &
\end{tabular}

${ }^{*} p<0,05$.

\section{DISCUSSION}

Infection, associated to ulceration and neuropathy is the main cause of lower limb amputation in persons with diabetes. ${ }^{2}$ The relevance of wounds in the lower limb of those patients is extremely important, since it can reach around 10-65/1000 patients per year, which is more than the rate of amputation, which can vary between 3.7 to $12.5 / 1000$ patients per year. ${ }^{7}$ In our study population, infection was present in 50.8 $\%$ of patients (osteomyelitis or infected ischemia), corroborating with the worldwide literature. It is also known that the risk of amputation in a diabetic patient is 10 to 15 times higher than in general population. ${ }^{8}$ The mortality of patients with late complications of diabetes is extremely high and is related to age, poor glycemic control and depression. ${ }^{9}$ Major amputations (ankle, transtibial or transfemoral) are associated with a lower survival rate than minor amputations (midfoot, rays or toes) ${ }^{10}$ which lead orthopedic surgeons to continually look for factors that may influence on the level of amputation to be selected.

On this study, minor amputations $(80,6 \%)$ were more frequent than major amputations (18.4\%). Despite the findings of Dillinghan et al, ${ }^{9}$ that patients with minor amputation are more often submitted to amputation revisions for a more proximal level, increasing the cost to the health system, we believe that the search for the most distal stump possible, regardless the healing time and the number of interventions necessary for such, decreases energy expenditure during walking, increasing the quality of life of post-amputated patients. It is believed that treating the patient in an early stage of neuropathy, allied to a multidisciplinary approach, positively influences limb preservation. ${ }^{11}$ All patients with ischemic injury, infected or not, in the lower limbs should receive clinical assessment by a general practitioner or endocrinologist, a vascular surgeon, an orthopedic surgeon, an infectious disease specialist, a plastic surgeon and a curative commissioner nurse, optimizing care and establishing priorities for the medical team.

Patients undergoing major amputations were those with more severe injuries indicated by a greater statistical frequency of associated ischemia and previous amputations. ${ }^{12,13}$ According to Pollard et al., ${ }^{6}$ patients with palpable dorsalis pedis pulse have better healing and do not require further amputation in most cases. Santos et al. ${ }^{14}$ found that patients with chronic arterial insufficiency without possibility of revascularization have a higher risk of a major amputation.

It should be noted that the use of ATB before surgery was a protective factor for major amputation, which may indicate that the use of empirical ATB can prevent the evolution of a simple to a severe injury, allowing smaller ablations.

Also related to ATB 's, it is noteworthy that the antibiotics used empirically followed the same frequency of use of the antibiotics oriented by the culture, being the use of Amoxicillin-Clavulanate the most frequent, followed by Ampicillin-Sulbactam and the combination of Ciprofloxacin and Clindamycin. Furthermore, it was observed that the use of preoperative ATB was a factor that decreased the patients wound closing time.

The type of intervention also affected the wounds closing time. Therefore, it should be attempted that, if the surgeon chooses to preserve the limb with vascular interventions and debridement, the wound closure time will be longer compared to a patient in which it is opted for ablative therapy.

Several laboratorial parameters influence the frequency of amputations. The nutritional status and patient immunocompetence are important factors when planning to perform an amputation in an individual with diabetes. It is known that SA levels below $3.0 \mathrm{~g} / \mathrm{dl}$ and total lymphocyte count less than $1,500 / \mathrm{mm} 3$ are considered poor prognostic factors leading to early progression of the amputation level. ${ }^{4}$ Furthermore, the presence of advanced kidney disease is an independent risk factor for major amputations. ${ }^{6,10}$ In this study, the 
only laboratorial parameter that presented statistical correlation was the number of preoperative leukocytes. The increase in leukocytes number was a predictor of a longer wound healing time, which is clearly explained by the fact that infected wounds present major challenges to the healing process.

\section{CONCLUSION}

This study shows that major amputations have as risk factors ischemia and previous amputations and as a protective factor the use ATB preoperatively. The wound healing time declines with the use of preoperative ATB and increases if the patient underwent vascular intervention or has higher Leukocyte levels preoperatively and / or had their member preserved, demanding multiple debridement.

\section{ACKNOWLEDGEMENTS}

We are grateful for our hospital medical records team, who made this retrospective analysis possible.

AUTHORS' CONTRIBUTIONS: Each author made significant individual contributions to this manuscript. DB (0000-0001-5404-2132)* and TB (0000-00019244-5194) were the main contributors to the drafting of the manuscript. DB (0000-0001-5404-2132), BM (0000-0001-8111-1500)*, RZ (0000-0001-9692-5283), FL (0000-0002-2967-627X)* and CN (0000-0002-9286-1750)* carried out the surgical procedures, performed patient follow-up and collected the clinical data. DB (0000-0001-5404-2132)*, TB (0000-0001-9244-5194)* and CN (0000-0002-9286-1750)* performed the literature review, revised the manuscript and contributed to the intellectual concept of the study. ${ }^{*} \mathrm{ORCID}$ (Open Researcher and Contributor ID).

\section{REFERENCES}

1. American Diabetes Association. Diabetes Statistics, 2012. [Accessed 21.08.2016]. Disponível em http://www. diabetes.org/diabetes-statistics.jsp /

2. Pecoraro R, Reiber G, Burgess E. Pathways to diabetic limb amputations. Basis for prevention. Diabetes Care. 1990;13(5):513-21.

3. Pinzur MS, Slovenkai MP, Trepman E. Diabetes Committee of American Orthopaedic Foot and Ankle Society. Guidelines for diabetic foot care: recommendations endorsed by the Diabetes Committee of American Orthopaedic Foot and Ankle Society. Foot Ankle Int. 2005;26(1):113-9.

4. Philbin TM, Leyes M, Sferra JJ, Donley BG. Orthotic and prosthetic devices in partial foot amputations. Foot Ankle Clin. 2001;6(2):215-28.

5. Lavery LA, Wunderlich RP, Tredwell JL. Disease management for the diabetic foot: Effectiveness of diabetic foot prevention program to reduce amputations and hospitalizations. Diabetes Res Clin Pract. 2005;70(1):31-7.

6. Pollard J, Hamilton GA, Rush SM, Ford LA. Mortality and morbidity after transmetatarsal amputation: retrospective review of 101 cases. J Foot Ankle Surg. 2006;45(2):91-7.

7. Reiber GE, Smith DG, Wallace C, Sullivan K, Hayes S, Vath C, et al. Effect of therapeutic footwear on foot reulceration in patients with diabetes: A randomized controlled trial. JAMA. 2002;287(19):2552-8.
8. Trautner C, Haastert B, Giani G, Bergert M. Amputations and diabetes: a case-control study. Diabetic Med. 2002;19(1):35-40.

9. Dillingham TR, Pezzin LE, Shore AD. Reamputation mortality heath care costs among persons with dysvascular lower limb amputations. Arch Phys Med Rehabil. 2005;86(3):480-6.

10. Larsson J, Agardh CD, Apelqvist J, Stenstrom A. Long-term prognosis after healed amputation in patients with diabetes. Clin Orthop Relat Res. 1998;(350):149-58.

11. Caputo GM, Cavanagh PR, Ulbrecht JS, Gibbons GW, Karchmer AW. Assessment and management of foot disease in patients with diabetes. N Engl J Med. 1994;331:854-60.

12. Davis WA, Norman PE, Bruce DG, Davis TM. Predictors, consequences and costs of diabetes-related lower extremity amputation complicating type 2 diabetes: the Fremantle Diabetes Study. Diabetologia. 2006;49(11):2634-41

13. Adler Al, Boyko EJ, Ahroni JH, Smith DG. Lower-extremity amputation in diabetes. Diabetes Care. 1999;22(7):1029-35.

14. Santos VP, Silveira DR, Caffaro RA. Risk factors for primary major amputation in diabetic patients. Sao Paulo Med J. 2006;124(2):66-70. 